\title{
"No me des el pescado, enséñame a pescar" "Do not hand me fish, teach me how to fish" Community Lawyering in Puerto Rico: Promoting empowerment and self-help
}

\author{
Myrta Morales-Cruz ${ }^{2}$
}

\section{Introduction}

Law 232 of August 27, 2004 has a special meaning to the people residing in some of Puerto Rico's poorest communities. It was the result of the hard work, during a period of a year and a half, of leaders from some of these communities and my students, the students of the community development section of the Legal Aid Clinic of the University of Puerto Rico's School of Law. The story of Law 232 can provide insight into what the role of a lawyer can be in the battle against poverty. To understand the story of this Puerto Rican law, one has to go back to August of 2002. During that month the University of Puerto Rico's School of Law Legal Aid Clinic inaugurated its community development section.

The community of Juan Domingo in the Municipality of Guaynabo had approached the Clinic before the community development section had started operating. Juan Domingo had been formed more than eighty years ago by squatters (or "land rescuers" as they prefer to be called). It was facing a removal process since the Municipality of Guaynabo, which has the highest per capita income in Puerto Rico, had decided to use the power of eminent domain against the community.

At the beginning of August, 2002, the director of the Legal Aid Clinic took me to a meeting in

1 Popular saying frequently used by Jorge Luis Oyola, leader of the Los Filtros community, located in Guaynabo, Puerto Rico. I want to thank Carmen Correa Matos, Hiram Meléndez Juarbe, Efrén Rivera Ramos, Dan Squires, William Vázquez Irizarry and Lucie White for their help with this paper. I dedicate this paper to the memory of my mother, Myrta Cruz Pérez.

2 Associate Professor of Law, University of Puerto
Rico School of Law. B.A., Georgetown University; J.D., University of Puerto Rico School of Law; LL.M., Harvard Law School; M.Jur., Oxford University. This is an expanded version of a paper that was originally presented at SELA (Seminar in Latin America of Constitutional and Political Theory) in June, 2005. The paper was subsequently published in Spanish by the University of Palermo (Argentina). 
Juan Domingo with the purpose of announcing to the community the opening of the community development section. At the time we did not know that the Juan Domingo community was holding a meeting to which it had invited other Guaynabo communities that were facing a similar problem.

Several days after the meeting in Juan Domingo, I received a phone call from Jorge Oyola, president of the neighborhood committee of the Los Filtros community, also located in Guaynabo, who had attended the Juan Domingo meeting. Mr. Oyola requested legal assistance for his community. On a Sunday night in September of 2002, I attended a meeting with my group of students and professor Carmen Correa, who at that time was also in charge of the community development section of the Clinic. We met with a group of thirteen people who comprise the Los Filtros neighborhood committee. That night they explained to us that they had knowledge of a plan by the Municipality of Guaynabo to use the power of eminent domain (initiate an expropriation process) against the community and they told us the story of their community. ${ }^{3}$

The Los Filtros community was founded over ninety years ago. At that time it was far away from the urban area, located in a rural area of Guaynabo. However, due to urban sprawl, the community is currently located in the middle of urban Guaynabo and it is surrounded by several of the richest neighborhoods in Guaynabo and in all of Puerto Rico. The cost of the roughly twelve acres of land, where the community is set and more than one hundred and twenty families live, is extremely high at the present time. ${ }^{4}$

During our first meeting in the community we were informed that the neighborhood committee had organized three months ago with the purpose of blocking the expropriation of the land which they owned. The committee had been successful in having the Urban Development and Housing Commission of the House of Representatives start an investigation about the proposed use of the power of eminent domain by the Municipality of Guaynabo against the Los Filtros community. Also, the committee had asked the state government to declare it a "special community".

The concept of a "special community" was coined by Sila María Calderón, former governor of Puerto Rico (2000-2004), while she was mayor of San Juan during the years 1996 to 2000. During her term as mayor, more than fifty low income communities in San Juan were designated "special communities". The main goals of this program were improving the infrastructure conditions in these communities and stimulating community empowerment. ${ }^{5}$ When Calderón became governor of Puerto Rico in 2001, the first law of her administration was the Law of Special Communities which extended the special communities program to the entire island.

When we first met with members of the Los Filtros community they explained to us that they had applied for admission to the special communities program since the mayor of Guaynabo had not submitted the community for inclusion. They told us that they wanted the protection that the Law

3 The power of eminent domain is the power of the State to take private property for public use upon payment of just compensation. Constitution of Puerto Rico, Article II, section 9.

4 There is a water treatment or water filtering plant next to Los Filtros, hence the name. The community was originally formed by the workers who came to build the water treatment plant and to work in a nearby dairy farm. They settled in the area with their families. In 1979 residents of the community were given title to the land by the State government.
5 The following criteria are taken into account in deciding whether a community is going to be declared a "special community": high percentage of illiteracy, high percentage of people living under the poverty threshold, high unemployment rate, families financially supported by only one member and a long history of environmental problems and of neglect in the provision of basic services. Law for the Development of Special Communities in Puerto Rico, Law 1 of March 1st, 2001, article 8, 21 L.P.R.A. sec. 967 (2004). 
of Special Communities offered to low income communities and that they wanted to be in charge of the development of their community.

One of our first tasks as legal advisors to the community was helping the committee to prepare for the public hearings that were going to be held at the House of Representatives in November, 2002, as part of the investigation of the expropriation process. The group of students analyzed the Law of Special Communities, the Law of Expropriation and the Law of Autonomous Municipalities.

The Law of Autonomous Municipalities granted the power of eminent domain (also known as expropriation or condemnation power) to municipalities in 1991.6 This power was granted subject to the requirements set by the Law of Expropriation. ${ }^{7}$ The Law of Expropriation, in accordance with the Puerto Rico Constitution, requires that the State have a "public use" in order to be able to exercise the power of eminent domain. ${ }^{8}$ However, the Supreme Court of Puerto Rico has interpreted the term "public use" in such a broad manner that it is practically impossible to be successful in questioning the "public use" alleged by the government. Even making an area look more attractive has been recognized as a valid "public use". ${ }^{9}$ On the other hand, a study of the Law of Special Communities revealed that the Office of Special Communities had no power over autonomous municipalities; it only required that the Office coordinate with autonomous municipalities projects in special communities. ${ }^{10}$

The Municipality of Guaynabo claimed that in the case of expropriation against Los Filtros its "public use" was the construction of "social interest" housing. However, the community had not been informed about the plans of the municipality. It was of great concern that the requirements in order to qualify for "social interest" housing that the Municipality of Guaynabo had established in a manual which the community had managed to obtain were strict, disqualifying many members of the community from such housing projects. For example, only people with "moderate income" qualified for these social interest housing projects. Neither people less than sixty two years old who lived alone, nor people who were not citizens of the United States qualified. ${ }^{11}$ The manual also stated that if a person did not accept the property value set by the Municipality of Guaynabo, she would not be eligible for social interest housing. ${ }^{12}$

Additionally, the members of the neighborhood committee had heard that the proposed housing

6 Puerto Rico's Law of Autonomous Municipalities, 21 L.P.RA. secs. 4051 (c) and 4453 (2004).

7 Law of Expropriation, 32 L.P.R.A. sec. 2901 et seq. (2004).

8 "Private property may not be taken except for public use and upon payment of just compensation as provided by law" (translated from Spanish), Constitution of Puerto Rico, Article II, section 9.

9 ELA v. 317.813 cuerdas de terreno, 84 D.P.R. 1 (1961).

10 Law for the Development of Special Communities in Puerto Rico, Law 1 of March 1st, 2001, article 4, 21 L.P.R.A. sec. 963 (2004).

11 Puerto Ricans are citizens of the United States.
Legal Permanent Residents of the United States, mostly Dominican citizens in the case of the Guaynabo communities, are excluded from these social interest housing projects.

12 This is particularly problematic since the social interest apartments that have already been developed by the Municipality of Guaynabo are subject to a mortgage for the amount of money that is owed after substracting the value of the condemned property from the much higher value that has been set for the new apartments. Another concern regarding the new apartment complexes are the maintenance fees that have to be paid for the communal areas. 
project was a small apartment complex. ${ }^{13}$ They feared, according to their own words, being caged "or "locked up in boxes". People were afraid of losing their sense of a close knit communal life. This life is very tied to the land, which they use to raise animals and harvest fruits and vegetables. They also feared losing the vegetation (plants and trees) of the community, which is one of the few green spaces left in urban Guaynabo.

After analyzing the applicable law, we explained to the Los Filtros neighborhood committee that it was practically impossible to block the expropriation process in court. If they wanted to block the expropriation their only option would be to seek a change in the statutes. The Law of Special Communities did not grant protection as the neighborhood committee had initially thought. We discussed, then, the possibility of seeking an amendment of this statute.

After studying the Law of Autonomous Municipalities we realized that municipalities had one particular limit on their use of the power of eminent domain: when they intended to use this power in relation to land currently owned by the State government or land that had been owned by the State government in the past 10 years. In such cases, the municipality had to obtain a Joint Resolution from the Legislative Assembly of Puerto Rico authorizing the expropriation. ${ }^{14}$ We decided that we could try to submit a similar amendment in the case of expropriation of land located in special communities. This would provide a public forum for the community and would give it an opportunity to present its position to the Legislative Assembly who would then have (together with the governor, who must sign Joint Resolutions for them to be valid), for all practical purposes, the final decision whether to authorize or not an expropriation process.

After much discussion we decided that ideally we would seek an amendment to the Law of Special Communities exclusively and that we would not seek to amend the Law of Autonomous Municipalities since the issue of the so called "municipal autonomy" was a very difficult political issue. Since 1991, when the statute was enacted, mayors from the two political parties that have alternated power in Puerto Rico have traditionally united to block all efforts that in any way would affect municipal autonomy. Also, the neighborhood committee wanted, in the words of their president, to "give more force" to the Law of Special Communities because they approved its public policy of favoring community empowerment.

Los Filtros is not the only community in Puerto Rico facing an expropriation process from an autonomous municipality. In addition to Juan Domingo and Los Filtros, the community of Mainé in Guaynabo approached the legal clinic in search of legal assistance. They are all part of a group of low income communities for which the Municipality of Guaynabo has expropriation plans. The Barriada Morales community in the Autonomous Municipality of Caguas also approached the legal clinic looking for help, after watching a television report about Juan Domingo

13 These types of small apartment complexes are known in Puerto Rico as "walk up apartments". The buildings are two to four stories high. Each floor usually has two apartments. The complexes have stairs, walkways, a small garden and a parking area which are all communal spaces. Currently people in
Los Filtros live in wooden or concrete houses that they have built, surrounded by plants and trees. From the highest points of the community there is a beautiful view of the entire Bay of San Juan.

14 Puerto Rico's Law of Autonomous Municipalities, 21 L.P.RA. sec. 4453 (2004). 
and showing up in the community to learn about what was happening. ${ }^{15}$ The community of Villa Caridad, located in the Autonomous Municipality of Carolina, was facing the same problem and sought legal assistance from the legal aid Clinic. ${ }^{16}$

In February of 2003, during a visit that the President of the Puerto Rico House of Representatives made to the community as part of the investigation process that the House had initiated, the students of the community development section of the Clinic discussed with him the proposed amendment to the Law of Special Communities. The president thought that the amendment was a good proposal, but warned the students that the mayors would pressure the district legislators to oppose the amendment. ${ }^{17}$ However, he remarked that he would be willing to submit a bill with the amendment since he strongly supported the public policy behind the Law of Special Communities.

The students drafted the bill and together with the Coalition of Communities United against Expropriations and Abuse, known as CCUCA, a coalition that was formed by the Los Filtros, Juan Domingo and Mainé communities in Guaynabo, the Barriada Morales community in Caguas and the Protectors of the Guaynabo River, started a lobbying process in the Puerto Rico House of Representatives. During the lobbying process we visited the offices of all fifty two representatives. Students and community residents explained the purpose of the bill and advocated that it be made into law.

It was of vital importance to CCUCA, the coalition, that the bill be embraced by leaders from the three main political parties in Puerto Rico. This was accomplished when the two minority leaders decided that they wanted to be co-authors of the bill, together with the President of the House.

The bill was assigned to the Urban Development and Housing Commission, which held public

15 Puerto Rico's Caribbean Business Magazine (October 23, 2003) published an article about autonomous municipalities in the island which highlights some of the reasons for the gentrification process (displacement of the poor by the rich in urban areas) that our clients are trying to avoid. The mayor of Guaynabo commented: "Municipalities work on a local level, with local investors... They come to me, I sit down with them and we do everything to make it happen. We provoke development...The sheer size of the central government doesn't allow it to have such close interaction with the investors, or even with the communities." According to this article the strategic plan for the Municipality of Guaynabo is based on the development of housing projects in order to increase its property tax base. The mayor continues explaining: "That way, you help the central government, the local government, and the municipal finances through the collection of property taxes. A resident can move out of Guaynabo, but the property will always pay property taxes, whereas a factory can close and take away your revenue." The mayor of Caguas commented: "I have to keep this business running and make the city more attractive each day so that more people come to shop, work, invest, enjoy shows, eat at our restaurants..." The same article concludes about the Municipality of Carolina that it "...is also aggressively pursuing its portion of property taxes collected by CRIM" (Center for Collection of Municipal Taxes). Guaynabo, Carolina and Caguas are all municipalities that surround the municipality of San Juan, Puerto Rico's capital. Urban sprawl has turned what were once rural areas into centrally located land that is being aggressively sought by private developers.

16 This problem is not exclusive to Puerto Rico. The Institute for Justice, a non governmental organization in the United States, published a study documenting the use of the power of eminent domain (by filing a case in court or threatening to file a case) with the purpose of benefiting private developers in more that 10,000 properties between 1998 and 2002. Dana Berliner, Public Power, Private Gain (2003) (available at www.ij.org or www.castlecoalition.org). Recently a case questioning the broad interpretation given to the term "public use" in eminent domain cases was brought before the United States Supreme Court. The Court validated "economic development" as a public purpose under the federal Constitution. Kelo v. City of New London, Connecticut, 545 U.S. 469 (2005).

17 The Puerto Rico Legislative Assembly has a group of legislators that win by accumulation of votes who do not respond to any particular voting district. These legislators are not as readily influenced by the mayors. 
hearings in July, 2003. The Clinic and CCUCA presented separate statements during the hearings. During the process of lobbying the Los Filtros community and CCUCA held numerous activities to further their cause, such as holding press conferences, appearing in radio and television programs and organizing protest marches and rallies, in which we participated and offered our help. ${ }^{18}$ The Clinic helped the Los Filtros community to connect with the Community Design Workshop of the University of Puerto Rico's School of Architecture. The community and the architecture students designed a development project for Los Filtros taking into account the needs and desires of the residents.

It was during the preparation for the public hearings that we had one of our most important and difficult discussions. The CCUCA had approached other community coalitions to inform them about the bill and obtain their support. It was suggested that the bill be amended to give greater protection to the communities. Instead of limiting itself to providing community involvement through the Joint Resolution mechanism, a referendum in which seventy-five percent of the community voted in authorization of the expropriation process was proposed as another community participation mechanism to be included in the bill.

This proposal was the subject of great debate among the members of the CCUCA, the San Juan Coalition of Community Leaders, my students and me. Our main concern was that adding the community referendum mechanism would make the approval of the bill more difficult, since that mechanism gave even more power to special communities facing an expropriation process by a municipality. We feared that advocating this mechanism would have the effect of not obtaining any mechanism at all, that proposing it would, so to speak, kill the bill.

After much discussion, we decided to simply mention at the end of the Clinic's statement during the public hearings that some communities had suggested a way of making the bill even more democratic by adding that in order for the Legislative Assembly to authorize by a Joint Resolution an expropriation process by a municipality in a special community, the community itself had to authorize the expropriation process by means of a referendum. We decided to observe closely the reaction of the representatives to this new proposal so that we then could decide what to do about it. The proposal was very well received by both the President of the House and the president of the commission that was holding the hearings. The bill was amended to include the community referendum, with the seventy-five percent requirement.

Statements were presented at the public hearings by CCUCA and the Clinic, as already mentioned, by the Office of Special Communities, which also supported the bill and by the Federation of Mayors and the Association of Mayors, organizations which group together the mayors from the two main political parties in Puerto Rico. Both the Federation and the Association strongly opposed the bill for its alleged interference with municipal autonomy. These two associations exert great influence over district legislators in Puerto Rico.

The State Office of the Commissioner for Municipal Matters also opposed the bill. The Justice Department favored the inclusion of a mechanism in order to protect special communities from unwarranted expropriations but it argued that the Office of Special Communities should have the final decision. This suggestion was openly discarded by the legal advisor of the Office of Special Communities during the public hearings.

18 The community development section of the Legal Aid Clinic helps and supports its clients in activities with the press and in political activities, but we limit our participation in order to promote client empowerment. 
The bill was approved unanimously by the House of Representatives in November, 2003. It was then sent to the Senate, where it was assigned to the Commission for Municipal Governments, Public Corporations and Urban Development. The group of students of the second year of the community development section of the Clinic and CCUCA were in charge of the lobbying process in the Senate. Once again, all the senators were lobbied and both the Clinic and CCUCA participated in the public hearings.

The bill was approved by the Senate on the last day of the legislative session, in June, 2004. The Senate decided to amend not only the Law of Special Communities, but also the Law of Autonomous Municipalities to include both mechanisms: the community referendum followed by the Joint Resolution in the case of expropriation in land located within special communities. The bill was sent to the Governor for her signature. After several visits to the Governor's mansion to continue our lobbying process, this time at the executive level, the Governor signed the bill, which became Law 232 of August 27, 2004.

Since January of 2005 Puerto Rico has a new government: a governor from the same political party as the former governor (who created the special communities program) and a legislative assembly controlled by a different political party. The two associations of mayors quickly lobbied the Governor's Mansion and the Legislative Assembly in order to repeal Law 232. Two bills were introduced to modify the law: one which repealed it in its entirety and another one (presented by the governor) which repealed the Joint Resolution mechanism. We have been able to prevent any tampering with Law 232 by attending public hearings, marching in front of the legislative building and aggressive lobbying. But, the struggle continues...

In May 4 of 2005, we won the first court cases in which Law 232 was raised as a defense. The Municipality of Guaynabo started filing expropriation cases against properties located in the Los Filtros community in December of 2004. My students asked for dismissal of the cases because of non compliance with Law 232. As I already mentioned, all cases were finally dismissed. If it had not been for Law 232 our only practical option would have been to request more compensation, but it would have been virtually impossible to question the "public use" alleged by the Municipality of Guaynabo because of the broad interpretation that the Supreme Court of Puerto Rico has made of the term.

The leader of the Los Filtros community has formed, together with leaders from other special communities, the Puerto Rico Alliance of Community Leaders. They have started organizing special communities all around the island. ${ }^{19}$ The Alliance is using Law 232 as an example of what poor people can achieve if they work hard together.

In our story neither the law nor the lawyers have provided a final solution to the displacement of poor people in Puerto Rico. Law 232 could be repealed at any moment. But we have used law as a tool for our clients to become more empowered, to gain more power for themselves and for their communities. We have made it clear to the communities that the true power to prevent their displacement lies in them.

I based the advocacy model of the community development section of the University of Puerto Rico's School of Law Legal Aid Clinic on the model developed by Professors Lucie White, of

19 There are close to seven hundred special communities in Puerto Rico. 
Harvard Law School, and Gerald López, of New York University's School of Law. It is an advocacy model that centers around process instead of results. López has referred to this model as one where the focus is on "process oriented client empowerment". ${ }^{20}$ Traditionally poverty lawyers have concentrated on developing legal strategies in order to obtain results: "result oriented legal strategies". ${ }^{21}$ López argues for a model more focused on the process, one that will allow the poor or low income client to take control of his or her situation and that will promote self-help and empowerment. $^{22}$

Professor Lucie White has written extensively about this type of advocacy model, which has been called by some commentators "law and organizing". ${ }^{23}$ Pedagogical work, based on a dialogue with the community, is crucial. The theory and methodology of popular education developed by the Brazilian educator and lawyer, Paulo Freire, are extremely useful in this type of work. ${ }^{24}$ Freire critiques traditional education by labeling it "banking education" since it presupposes that there is an "empty brain", that of the person to be educated, where the educator "deposits" information. For education to be truly transformative it should start from the experience of the participants and be based on dialogue and action; it must be a participatory experience, generating a process of "consciousness raising". 25

As early as 1970, Steven Wexler, in an article published in the Yale Law School Law Review, had remarked that since the problems of the poor are fundamentally problems of a social nature, not individual problems, poor people had to organize and act for themselves. To support this process, poverty lawyers had to radically depart from the traditional lawyering role and do work similar to that of a teacher, turning each moment into an occasion for poor clients to practice skills and establish networks that would allow them to make change. ${ }^{26}$

Lucie White has described three visions of how the "public interest" or "progressive" lawyer promotes change. ${ }^{27}$ The first image of lawyering is the contest of litigation. In this image the lawyer's role is to design and win lawsuits that will further the substantive interest of the client. The lawyer "translates" grievances into legal claims. ${ }^{28}$ In this image of lawyering the lawyer does not question the structure of the law itself, by asking whether it sometimes prevents him or her from translating the client's grievances into good legal claims. White adds: "Nor is it his role to question the judicial system, asking whether it sometimes prevents him from securing remedies that really work." 29 The lawyer uses the courts as a direct mechanism for redressing injuries and redistributing power to subordinated groups. In this image of lawyering the client is "in the background". ${ }^{30}$

As White remarks, public interest litigation has brought about substantive change. However, in some circumstances "courts have difficulty fashioning adequate remedies." 31 This can happen when the structure of a bureaucracy or its routine discretionary functioning is questioned and "courts find it difficult to craft and implement effective relief". ${ }^{32}$ Another example is where the

20 Gerald López, Rebellious Lawyering: One Chicano's Vision of Progressive Law Practice (1991).

21 Id.

22 Id.

23 See, for example, Lucie White, To Learn and to Teach: Lessons from Driefontein on Lawyering and Power, 1988 Wis.L. Rev. 699.

24 Paulo Freire, Pedagogy of the Opressed (1970).

25 Id.
26 Steven Wexler, Practicing Law for Poor People, 79 Yale L.J. 1049 (1970), as cited by White, supra note 23.

27 See Lucie White, supra note 23.

28 Id. at 755.

29 Id.

30 Id. at 756.

31 Id.

32 Id. 
courts have limited jurisdiction to redress an inadequate appropriation of public funds, which can be the root of many problems. ${ }^{33}$

The most serious limitation of this image of lawyering is that in order to get into court, clients must present their claims as similar to precedent claims that courts have already accepted. Litigants must propose remedies that are "coextensive with these confined claims and that can be feasibly administered by the courts". ${ }^{44}$ This can result in co-opting social mobilization. As White concludes: "Through the process of voicing grievances in terms to which courts can respond, social groups risk stunting their own aspiration. Eventually they may find themselves pleading for permission to conform to the status quo." 35

The second image of lawyering presented by White is "law as a public conversation". In this image the lawyer recognizes that litigation can sometimes work to change the distribution of social power, but these effects are secondary to "law's deeper function in stimulating progressive change". 36 Litigation can coerce change but it "is also public action with political significance." 37 The law and its practice constitute a discourse about social justice; it has a cultural meaning. ${ }^{38}$

In the second image of lawyering success is not measured by a whether a case is won. It is rather measured by such factors as "whether the case widens the public imagination about right and wrong, mobilizes political action behind new social arrangements, or pressures those in power to make concessions". ${ }^{39}$ A limitation of this image of lawyering is that it cannot respond to subordinated clients who do not perceive their grievances clearly, the ones that have a more realistic assessment of the their options, the ones that distrust the "system". These clients never get the attention of the lawyer. ${ }^{40}$ White suggests that the lawyer work with these groups of subordinated people in a joint project of "translating felt experience into understandings and actions that increase their power". ${ }^{41}$ This is the third image of lawyering: "lawyering together toward change".

The third image of lawyering has two main components: pedagogy based on dialogue and strategic work. Paulo Freire's popular education theory and the feminist methodology of "consciousness raising" can be very useful in this type of lawyering:

Freire's work shows how an active, critical consciousness can re-emerge among oppressed groups as they reflect together about concrete injustices in their immediate world and act to challenge them. He views this liberation of consciousness as fundamentally a pedagogic process. It is an unconventional, nonhierarchical learning practice in which small groups reflect together upon the immediate conditions of their lives. ${ }^{42}$

According to White, in this pedagogic model, no one monopolizes the role of the teacher. Humility is crucial for the lawyer who wants to venture into this type of work. There can be no real dialogue if the lawyer believes that he or she has privileged knowledge about reality or politics. The lawyer has to recognize his or her position as an outsider and earn the clients' trust. ${ }^{43}$

$33 I d$.

34 Id. at 757.

35 Id.

36 Id. at 758 .

37 Id.

38 Id.
39 Id. at $758-759$.

40 Id. at 760 .

41 Id.

42 Id. at 761.

43 Id. at 762. 
Lawyering in the third image also involves strategic work. The lawyer must help the clients to plan concrete actions "that challenge the patterns of domination that they identify". ${ }^{44}$ This is a learning process where the clients learn to view their relationship with those in power not as a static condition, but rather as "an ongoing drama".

The lawyer has to help the group "learn how to interpret moments of domination as opportunities for resistance" ${ }^{46}$ :

The lawyer cannot simply dictate to the group what actions they must take. Neither the lawyer nor any single individual is positioned to know what actions the group should take at a particular moment. Sound decisions will come only as those who know the landscape and will suffer the risks deliberate together. The role of the lawyer is to help the group learn a method of deliberation that will lead to effective and responsible strategic action. ${ }^{47}$

White asks why this work should be thought of as lawyering at all. She answers that fluency in the law, defined as "a deep practical understanding of law as a discourse for articulating norms of justice and an array of rituals for resolving social conflict" 48 will improve a person's effectiveness and flexibility in this type of work:

An understanding of law as discourse on norms will help [the lawyer] work with the clients to deepen their own consciousness of their injuries and their needs. Knowledge of the law's procedural rituals will give the group access to a central arena for public resistance and challenge. It is also possible, however, that professional identification as a lawyer can narrow one's strategic imagination. Perhaps the best arrangement is for lawyers-outsiders to work side by side with outsiders trained in other fields. ${ }^{49}$

The community development section of the Clinic's advocacy model can be compared to the second and third images of lawyering discussed by White. We are using law to widen the public's imagination about right and wrong, to mobilize political action behind new social arrangements and to pressure those in power to make concessions. Our work has exposed the injustice of using the power of eminent domain for gentrification purposes. We have mobilized political action to protect the poor from displacement and to support the development of housing projects by the communities themselves; and we have pressured the executive and legislative branches of government into supporting our clients.

But we are, most importantly, focusing on pedagogy based on dialogue and strategic work to promote client empowerment, and engaging in multidisciplinary work. Our work is a mutual learning process: we learn from the communities and the communities learn from us. ${ }^{50}$ For example, our clients have learned more about the law. Statutes, judicial opinions and law in its broadest sense have been demystified for them. We have learned much about the reality of poor people, about their day to day struggle, and about politics, among other things. Our strategies are

44 Id. at 763.

45 Id.

46 Id.

47 Id. at $763-764$.

48 Id. at 765 .
49 Id.

50 Defining who the client is can sometimes be difficult in community lawyering. We have chosen to address this issue by focusing on working with neighborhood committees democratically elected by a community. 
devised together. This process of mutual collaboration and learning has made our work together more effective. Finally, engaging in multidisciplinary work with other professionals, such as architects and community social workers and psychologists, has helped us to better address the problems of the community as a whole.

Our advocacy model can also be compared to business or corporate lawyering. ${ }^{51}$ Our clients, like corporate clients, are "clients for life". 52 We counsel them without limiting our strategies to litigation, or to purely legal approaches, and we help them to design and implement long term strategies so that they can gain more power in our society.

During our work, we have noticed that lobbying has been a very successful tool for corporate lawyers in Puerto Rico. The largest law firms in Puerto Rico incorporate legislative and executive lobbying as part of their work or have lobbying divisions..$^{53}$

We have found lobbying to be a good strategy for promoting empowerment among our clients. In the court, we, the lawyers, are in control of the process. Lobbying makes it easier for us to work side by side with our clients. They gain power as they speak and argue about their situation, about the law, about how the law should be... Their voice is independent from our voice as lawyers. Focusing on the legislative branch also makes it easier for our clients to gain access to the press and to make alliances with other community groups, which helps to create more public discussion about the issues. The public hearings have been crucial in the empowerment process. Finally, the fact that a statute, once approved, has a direct impact on more people that an average court decision, helps to bring more people into the process and furthers collective empowerment. ${ }^{54}$

51 See Lawyering for Poor Communities in the TwentyFirst Century, the Seventh Annual Stein Center Symposium on Contemporary Urban Challenges, articles published in 25 Fordham Urban Law Journal (1998).

52 Susan D. Bennett, On Long-Haul Lawyering, 25 Fordham Urban Law Journal 771 (1998).

53 Since the 1980s attorneys working for institutions funded by the Legal Services Corporation, which is the case of most of the organizations providing free legal services in civil cases in the United States and Puerto Rico, cannot engage in lobbying, organizing or class action lawsuits. Id. at 775 (quoting United States federal statutes that prohibit such activities). Lawrence Friedman has suggested that the access to justice problem in the United States is not that the poor have no counsel, but rather a problem with what the poor would demand if they had adequate counsel. Lawrence Friedman, Access to Justice: Some Comments, 73 Fordham Law Review 927 (2004).

54 I want to clarify that I am not suggesting that the legislative process is fairer than the judicial process. The rich can make their voices heard more easily in the legislative branch, just as they can in the courts. My perception so far has been that engaging in the legislative process creates more opportunities for the voices of the poor to be heard and for collective empowerment. Much could be written about the difficulties of lobbying such as, for example, that it is extremely time consuming, but that could be the subject of another paper. 
Our work is trying to open spaces of what Boaventura De Sousa Santos calls "direct participatory or base democracy". De Sousa Santos advocates radicalizing democracy by creating more spaces of participatory democracy. He believes that the postmodern project of participatory democracy will prevent the destruction of the modern project of representative democracy, and that the struggle for extra economic or post materialist goods, such as the environment or peace, a postmodern struggle, will be conditioned by the modern struggle for the redistribution of economic goods. ${ }^{55}$

The story of Law 232 shows how representative democracy can be used to open spaces for direct participatory democracy. If we had adopted a more traditional litigation approach as lawyers, our clients would have already been displaced from their communities. But more importantly, the opportunities for empowerment would have been lost. Our work together has been a process of mutual learning. The communities with which we have worked have gained access to the political process and have formed an alliance with communities all over Puerto Rico. They have organized, protested, marched, held press conferences, prepared their own development projects... Their voice is being heard. The primary power to radicalize our democracy by continuing to create true spaces of participation resides in them.

55 Boaventura De Sousa Santos, The Postmodern Transition: Law and Politics (1991) [from Lloyd's Introduction to Jurisprudence (sixth edition 1994). De Sousa Santos explains his progressive political postmodern theory (at 1208-1209):"The proliferation of political interpretive communities represents the postmodern way and, indeed, the only reasonable way of defending the accomplishments of modernity. I mentioned earlier, among such accomplishments, a fairer distribution of economic resources and a significant democratization of the political system in the conventional sense. As with all processes of transition, the postmodern transition also has a dark side and a bright side. The dark side is that, as the reification of class and the state are further exposed, the modern tools used until now to fulfill and consolidate those promises, that is, class politics and the welfare state, become less reliable and efficient. The proliferation of political interpretive communities will broaden the political agenda in two convergent directions. On the one hand, it will emphasize the social value of extraeconomic goods or postmaterialist goods such as ecology and peace: on the other hand, it will expand the concept and the practice of democracy in order to incorporate direct participatory (or base) democracy. The success of the struggle for extraeconomic goods will be conditioned by the success of the struggle for economic goods and for a fairer distribution of economic resources. The struggle for participatory democracy will prevent the emasculation of representative democracy. It is in this sense that the promises of modernity can only be defended, from now on, in postmodern terms." 